\title{
コンクリート壁の耐火性能に及ぼす調合と含水率の影響 ON THE EFFECT OF MIX DESIGN AND WATER CONTENT UPON THE FIRE RESISTANCE OF CONCRETE WALLS
}

\author{
原田和典*, 寺井俊夫** \\ Kazunori HARADA and Toshio TERAI
}

\begin{abstract}
Variations of the fire resistance of concrete walls were numerically analyzed using a model of heat and mass transfer. The analysis was made in two steps. In the first step, the material properties such as thermal conductivity and density were estimated based on the mix design. Then, in the second step, the values are used in the model of heat and mass transfer, which gives the estimate of fire resistance time. By repeating this procedure, the variation due to the mix design of concrete was quantified. In a similar way, the variation due to the change of initial water content was also quantified. As a result, the effect of mix design dominates the variation of fire resistance of concrete. The effect of initial water content is sinall compared with that of mix design. Thus the effect can be approximated by a liner relationship as 3.3 minutes per $1 \%$ change in initial water content in case of $70 \mathrm{~mm}$ thick walls. By using this result, a diagram was presented to show the range of acceptable mix design for the required fire resistance time.
\end{abstract}

Keywords : fire resistance, concrete, heat and mass transfer, mix proportions, initial water content, 耐火性能、コンクリート、熱水分移動、調合、初期含水率

\section{1. 序}

コンクリート部材の熱的性質は、調合（骨材の種類と 量）や養生条件（含水率）により大きく変化するが、そ れが耐火性能に及ぼす度合は現在のところ正確には不明 であり、より合理的な耐火設計法の確立を阻む要因と なっている。

これを標準火災試験2，3)等の実験的手法を用いて解明 することは、原理的には可能であるが時間と費用の面か らは不可能に近い。たとえば Lee らはコンクリート柱の 耐火試験を多数行ない、粗骨材の種類による影響が大き いことを示しているが、定量的な関係を導くまでには 至っていない4)。

それゆえ、解析的手法によりこれを定量化することが 望まれている。本研究では、耐火試験におけるコンク リート壁の温度上昇を熱水分移動モデルにより解析し、 コンクリートの調合と含水率の変化が耐火性能に及ぼす 影響を調べる。

\section{2. 解析方法}

調合と含水率が耐火性能に及ぼす影響を調べるため、 Fig. 1 に示す方法を用いる。はじめに、コンクリートの 調合および含水率を想定し、それに基づき熱水分移動に 関する物性値を推算する(step 1)。推算値を熱水分移動 モデルに用いて数値解析を行い(step 2)、その結果から 耐火時間を評価する。この手順を多くの条件について繰 り返せば調合および含水率と耐火時間との間の定量的な 関係を得る。なお、耐力壁の場合には力学的な検討も必 要になるが、本研究では非耐力壁に限ることとし、力学 的な検討は行わない。

検討対象は、厚さ70mmのコンクリート平面壁とした。 平面壁としたのは、一次元問題となり、解析と考察が簡

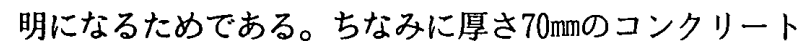
壁は、現行の法令基準では 1 時間の耐火性能が認定され ている5)。

\footnotetext{
本研究の一部は，第 1 回アジア火災科学技術会議”にてロ頭発表した。

* 京都大学工学部建築学科 助手. 博士(工学) Instructor, Dept. of Architecture, Kyoto University, Dr. Eng.

** 近畿大学工学部建築学科 教授. 工博 Prof., Dept. of Architecture, Kinki University, Dr. Eng.
} 
加熱条件は ISO 8342）とし、片側より標準加熱曲線

$\theta_{f}=345 \log _{10}(8 t+1)+\theta_{0}$

に規定される温度に従って加熱される場合を想定した。 ただし、 $\theta_{0}$ は初期温度、時間 火性能の評価もIS0 834 に基づき、非加熱側表面の温度 が $140^{\circ} \mathrm{C}$ 上昇するまでの時間を耐火時間として定義する。

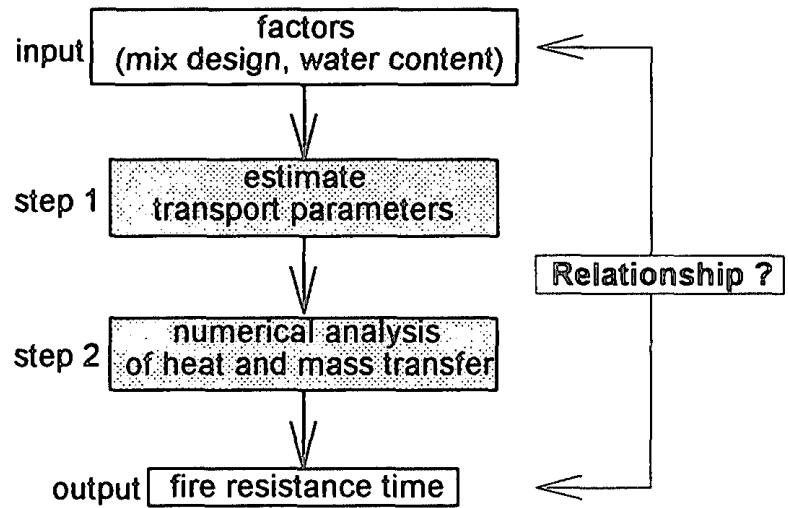

Fig.1 a flow chart to analyze the variation due to mix design and due to initial water content

\section{1 熱水分移動モテル}

Fig. 2 に示すようにコンクリートを多孔材料として扱 う。実質部の熱伝導、空隙内のガス（空気、水蒸気）の 抬散之対流、物理吸着水（含水）の脱着および抾散、結 晶水の熱分解を考虑すると次式が適用できる6）。

（熱収支）

$\rho c \frac{\partial \theta}{\partial t}=\nabla(\lambda \nabla \theta)-L_{s} R_{\text {sorp }}-L_{d} R_{d c m p}$

（空陌内ガスの収支）

$\frac{\partial\left(\varepsilon \rho_{g}\right)}{\partial t}+\nabla\left(\rho_{g}\right.$ घ) $)=R_{\text {sorp }}+R_{d c m p}$ $\frac{\partial\left(\varepsilon \rho_{v}\right)}{\partial t}+\nabla\left(\rho_{v}\right.$ u $)=\nabla\left(D_{v} \nabla \rho_{v}\right)+R_{\text {sorp }}+R_{d c m p}$

（物理吸着水および結晶水の収支）

$\rho_{0} \frac{\partial w}{\partial t}=\nabla\left(\rho_{0} D_{w} \nabla w\right)-R_{\text {sorp }}$

$\rho_{0} \frac{\partial w_{c}}{\partial t}=-R_{d c m p}$

ただし

（空隙内ガスの移動速度）

थ $=-\kappa_{D} \nabla P_{g}$

（物理吸着水の脱着速度）

$R_{\text {sorp }}=\gamma\left(w-w_{\text {eq }}\right)$

（結晶水の熱分解速度）

$R_{d c m p}=\rho_{0} \sum_{k=1}^{3} w_{c, k} A_{k} \exp \left(-E_{k} / R T\right)$

（気体の状態方程式）

$\rho_{v}=\frac{M_{v} P_{v}}{R T}$

$\rho_{g}=\rho_{v}+\rho_{a}=\frac{\left(M_{v}-M_{a}\right) P_{v}+M_{a} P_{g}}{R T}$

である。式(9)における添字 $k=1$ はゲルの崩壊(100〜 $\left.400^{\circ} \mathrm{C}\right)$ を、 $k$-2はポルトランダイト相 $\left(450 \sim 550^{\circ} \mathrm{C}\right) 、$ $k$-3はCSH相の分解 $\left(600^{\circ} \mathrm{C} \sim\right)$ を表し、 $w_{c, k}$ はそれぞれの 成分の残存量である。

数値解析では、Fig. 3 に示す要素分割を用い、各要素 の温度 $\theta$ 、空隙内ガスの全圧 $P_{g}$ 、水蒸気分圧 $P_{v}$ 、物理吸 着水の含水率 $w$ および結晶水の含水率 $w_{c}$ を末知数とする 定式化を行った。数值解法の詳細は既報に示した7)。境 界条件と初期条件は Table 1 の值を用いた。
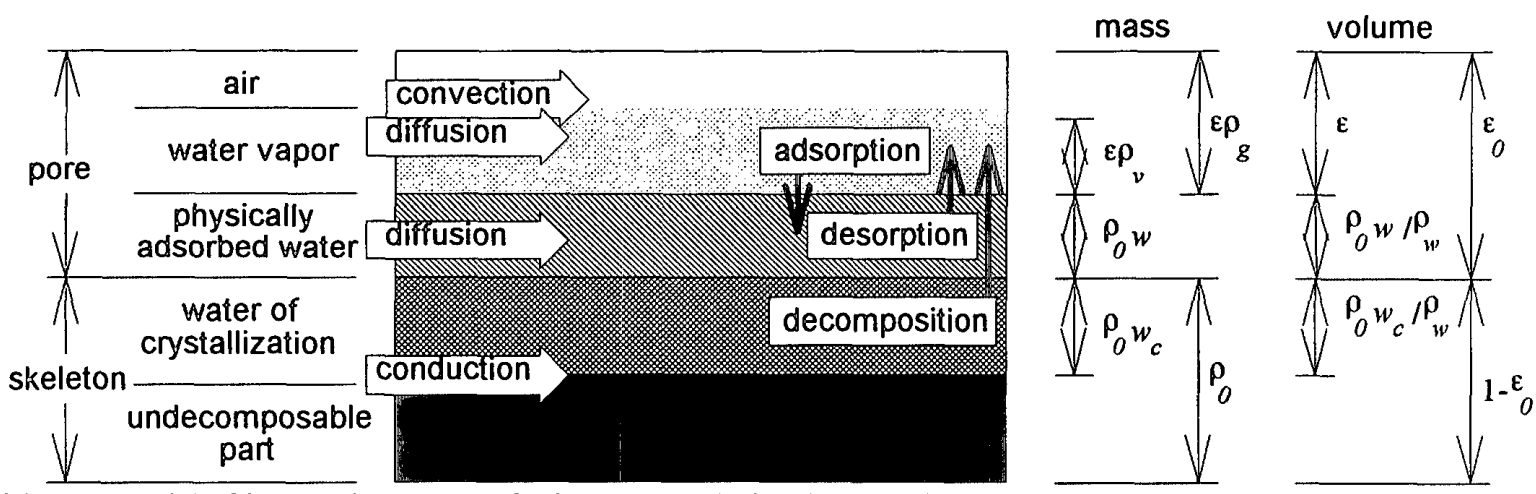

Fig.2 a model of heat and mass transfer in concrete during fire, considering the heat conduction, gas filtration, diffusion of water vapor and physically adsorbed water. These phenomena are coupled by sorption and decomposition 


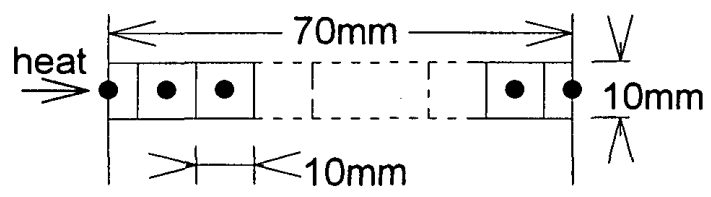

Fig.3 division of wall slab into elements.

Table 1 boundary condition parameters

\begin{tabular}{lcc}
\hline & $\begin{array}{c}\text { exposed } \\
\text { surface }\end{array}$ & $\begin{array}{c}\text { unexposed } \\
\text { surface }\end{array}$ \\
\hline convective coeff. $\left[\mathrm{W} / \mathrm{m}^{2} \cdot \mathrm{K}\right]$ & 23 & 23 \\
ambient temperature $\left[{ }^{\circ} \mathrm{C}\right]$ & ISO $834^{*}$ & 4 \\
resultant emmisivity $[-]$ & 0.3 & 0.0 \\
vapor transfer coeff. $[\mathrm{m} / \mathrm{s}]$ & 0.002 & 0.0006 \\
\hline initial temp. $\left[{ }^{\circ} \mathrm{C}\right]$ & \multicolumn{3}{|c}{4} \\
initial water cont. [\%-wt.] & \multicolumn{3}{|c}{} \\
\hline
\end{tabular}

*) see eq.(1)

\section{2 コンクリートの調合と物性值の関係}

上述のモデルを用いて、コンクリートの調合と耐火性 能の関係を定量化するためには、モデルに現れる物性值 と調合との関係が必要になる。これらは、材料単体での 物性値之、混合比率 (単位容積重量) をもとに推算する ことが可能である。ここでは、その方法の概要を示す。 詳細は文献8)に示されている。

コンクリート全体の体積のうち、粗骨材、細骨材、セ メントペーストのそれぞれの体積比率を $V_{a g} 、 V_{s} 、 V_{p}$ と する。密度、比熱、空隙率については、各構成材料の值 を単純加算すれば良いので

$\rho=\sum_{i} \rho_{i} V_{i}$

$\rho c=\sum_{i} \rho_{i} c_{i} V_{i}$

$\varepsilon_{0}=1-\sum_{i} V_{i}$

となる。ここに、添字 i は ag（粗骨材）、s（細骨材）、 p（セメントペースト）のいずれかを表す。

熱伝導率については、Maxwellの式9)により二種混合 材料の值を推算できる。 $\mathrm{i}$ 種（連続相）と $\mathrm{j}$ 種（分散 相）を(1-v)対 $v$ の体積比率で混合した材料の熱伝導率 $\lambda_{i+j}$ は

$\lambda_{i+j}=\lambda_{i} \frac{\lambda_{j}+2 \lambda_{i}-2 v_{i}\left(\lambda_{i}-\lambda_{j}\right)}{\lambda_{j}+2 \lambda_{i}+v_{i}\left(\lambda_{i}-\lambda_{j}\right)}$

により与えられる。

数種の粗骨材と砂については、それら単独での密度、 比熱、熱伝導率が Table 2、Fig.4、5 のように得られて おり10〜12)、これらを任意の割合で混合した時の值は 式(12)〜(15)により計算できる。式(15)を、ペーストと
砂の混合、モルタルと粗骨材の混合の二段階に適用すれ ば任意の調合のコンクリートの熱伝導率を得ることがで きる。

透気率、水蒸気拡散係数、液状水拡散係数などの物質 移動係数は、温度上昇過程に対する感度が低いこともあ り、簡単のため空隙率依存性のみを考虑した。詳細は文 献8)に示した。

Table 2 density and specific heat of constituents

\begin{tabular}{lcc}
\hline & $\begin{array}{c}\text { density } \\
{\left[\mathrm{kg} / \mathrm{m}^{3}\right]}\end{array}$ & $\begin{array}{c}\text { specific heat } \\
{[\mathrm{J} / \mathrm{kg} . \mathrm{K}]}\end{array}$ \\
\hline cement & 3150 & 920 \\
sand & 2650 & 830 \\
lightweight aggregate & 1550 & 795 \\
basalt & 2500 & 896 \\
sandstone (1) & 2690 & 829 \\
sandstone (2) & 3600 & 862 \\
tuff & 3600 & 858 \\
chart & 4000 & 828 \\
\hline
\end{tabular}

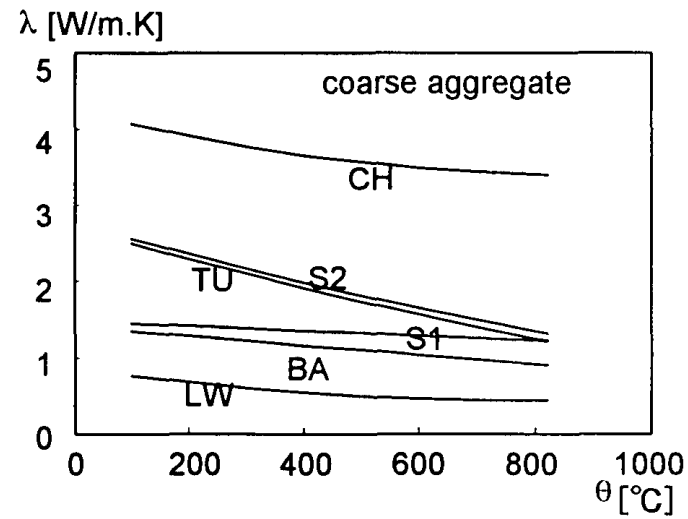

Fig.4 thermal conductivity of coarse aggregates ( $\mathrm{LW}=$ lightweight, $\mathrm{BA}=$ basalt $, \mathrm{S} 1, \mathrm{~S} 2=$ sandstone, $\mathrm{TU}=$ tuff, $\mathrm{CH}=$ chart)

$\lambda[\mathrm{W} / \mathrm{m} . \mathrm{K}]$

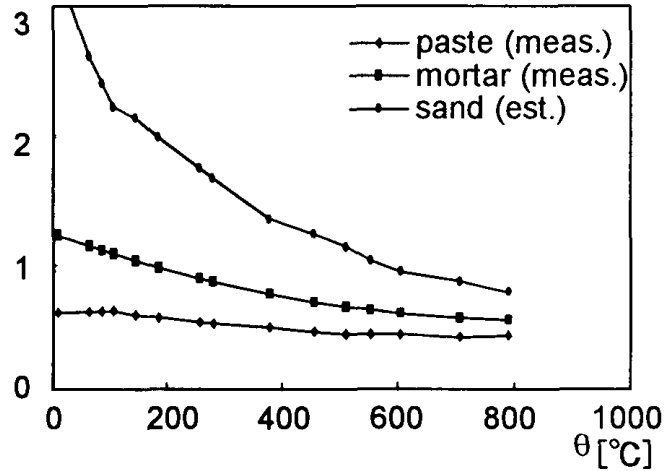

Fig.5 thermal conductivity of cement paste, cement mortar and sand.

\section{3 予濉精度の検討}

ここで、上述の方法の精度について検討しておく。 Fig. 1 に示したように予測は二段階からなり、ステップ 
1では、コンクリートの調合から物性値を推算する。予 備的に行った感度解析によれば、熱伝導率の感度が非加 熱側表面温度経過に対しては圧倒的である。ゆえに、熱 伀導率の推算靖度が解析全体の精度を左右する。

調合が既知のコンクリートの高温時の熱伝導率を測定 した例はあまり多くないが、上田らは砂岩コンクリート と軽量コンクリートの值を報告している13)。この調合 から推算した值を測定値と比較した結果を Fig. 6 に示す。 これより、推算值は測定値よりも平均で約 $10 \%$ 大きめ の結果を与え、標準愦差は約 8 \%である。

現状では比較できるデータが十分ではないため、明確 な結論を下すまでには至らないが、本推算法は多くの場 合熱伝導率を過大に評価する側の俱差を持つようである。 熱伝導率が過大であると、ステップ2 の耐火性能予測で は耐火時間を短く評価する側の愦差を生ずる。他の物性 值については感度が低いので、推算値に俱差があっても 熱伝導率の俱差の影響に比へて相対的に無視しうる。

解析の第 2 ステップでは、熱水分移動モテルが持つ理 論俱差が介在しうる。モデル自体の精度検証のため、モ ルタル平版を実験に供した。その一方で、同一調合のモ ルタルについて熱伝導率を測定し、その値を用いて計算 を行った。両者は非常に良く一致し6,14)、モデル自体 が有する理論誤差は、ステップ1の熱伝導率の推算俱差 に比へて無視しうる。

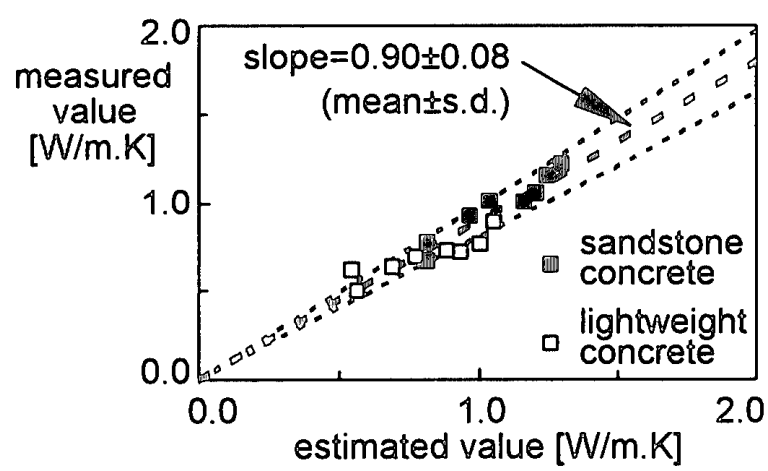

Fig.6 prediction error in thermal conductivity of sandstone and lightweight concrete. Data were measured by Ueda et al. 13 )

\section{3. 解析}

3. 1 コンクリートの調合と耐火性能の関係

\section{(1) 骨材の種類による影響}

粗骨材、細骨材、セメントペーストの体積比率を Table 3 の値に固定し、粗骨材の種類を人工軽量骨材

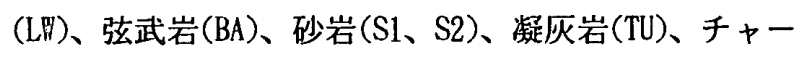
ト(CH)の 6 種類の骨材のいずれかとした場合について計 算を行った。推算した熱伝導率を Fig. 7 に、絶乾密度を Fig. 8 に示す。粗骨材の種類により熱伝導率は大きく変
化し、最む大きいのはチャート、最む小さいのは人工軽 量骨材である。

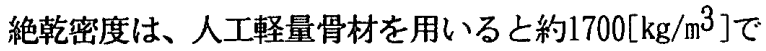
あるが、比重が大きな骨材 (S2、TU) を用いると2400程度 となり、全体で約 2 割強の変動がある。

コンクリートの初期含水率は砂岩(S1)については3\%-wt. とした。他の調合のコンクリートでは絶乾密度が異なる ため、単位体積あたりの含水量が等しく $63\left[\mathrm{~kg} / \mathrm{m}^{3}\right]$ となる ように值を設定した。

Table 3 mix proportion of concrete

\begin{tabular}{lc}
\hline & $\begin{array}{c}\text { volume fractions } \\
{\left[\mathrm{m}^{3} / \mathrm{m}^{3} \text {-bulk }\right]}\end{array}$ \\
\hline coarse aggregate* & 0.362 \\
fine aggregate & 0.299 \\
cement & 0.087 \\
water & 0.068 \\
\hline sum & 0.816 \\
\hline
\end{tabular}

* LW, BA, S1, S2, TU or CH

* hydrated water only. (Excl. excess water)

\section{$\lambda[\mathrm{W} / \mathrm{m} . \mathrm{K}]$}

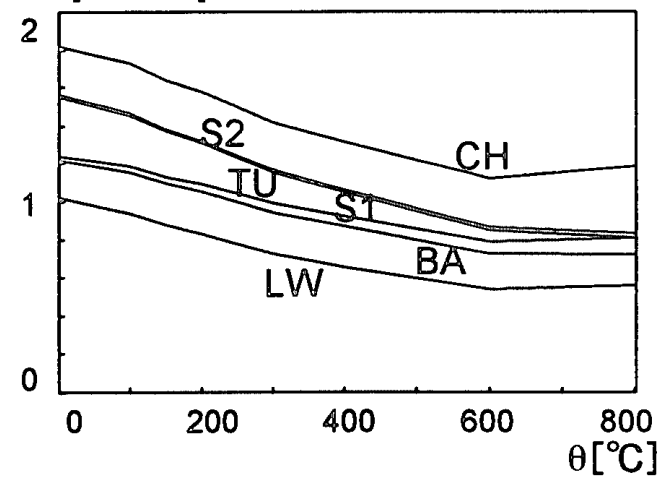

Fig.7 estimated thermal conductivity of six kinds of concrete (See Fig. 4 for symbols. Mix proportions are shown in Table 3)

type of aggretage

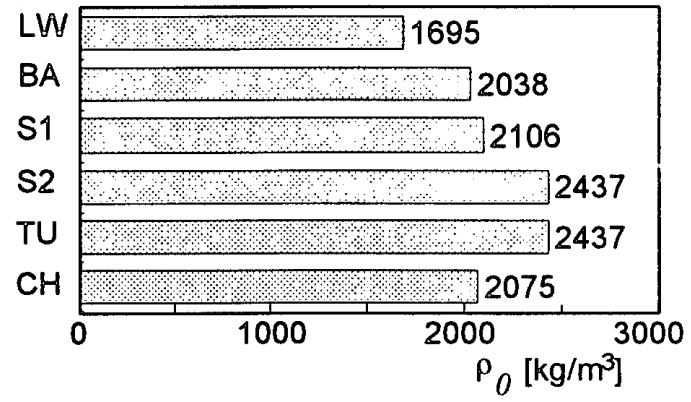

Fig. 8 estimated density of six kinds of concrete (oven dry condition, See Fig. 4 for symbols.)

計算結果から非加熱側表面温度の経過のみを抽出して Fig. 9 に示す注1)。骨材の種類により温度経過が大きく 
影響され、温度の横ばい（物理吸着水の脱着に伴う潜熱 吸収のため温度上昇が一時的に停滞する現象）の継続時 間は約9 20分の間で変動する。温度が $140^{\circ} \mathrm{C}$ 上昇するま での時間を耐火時間として定義すると54〜83分となる。 熱伝導率の大小と耐火時間の長短とは良く対応しており、 熱伝導率が大きいほど耐火時間は短くなる。

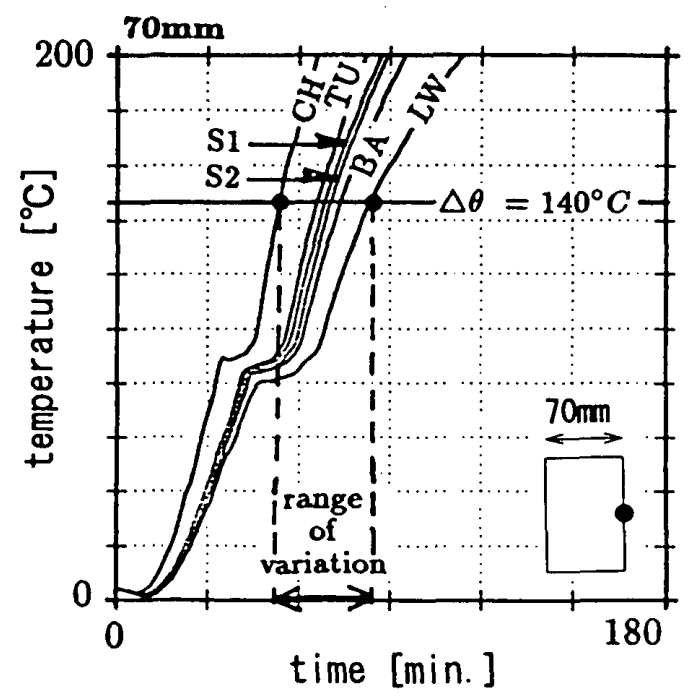

Fig.9 calculated unexposed surface temperature for different kind of aggregate. (See Fig. 4 for symbols.)

\section{（2）骨材の量による影響}

前項の検討により、粗骨材に軽量骨材(LW)を用いると 温度上昇が最も遅く、チャート $(\mathrm{CH})$ を用いると最も温度 上昇が早いことが明らかとなったので、これら 2 種類の 骨材について体積比率 $V_{a g}$ を $0 \sim 0.43\left[\mathrm{~m}^{3} / \mathrm{m}^{3}\right]$ の範囲で変 化させた。

推算した熱伝導率を Fig. 10 に示す。チャートでは体 積比率が増加するに従って熱伝導率は大きくなる。一方、 人工軽量骨材ではモルタルの值からわずか小さくなる 程度である。

非加熱側表面温度の経過をFig. 11 に示す。前項之同様 に、熱伝導率と耐火時間とは良く対応している。チャー トでは粗骨材量が増えるにつれて耐火時間が短くなるが、 人工軽量骨材ではその変化はほとんど無い。

\section{2 初期含水率の影響}

コンクリートの含水状態はその耐火性に複雑な影響を 及ぼす。一般に高含水率のコンクリートは熱伝導率が大 きいので、この点では耐火性能に対して不利に㗢く。一 方、含水率が高いコンクリートは物理吸着水の脱着に要 する熱量が増加するので温度の横ばい現象が長い時間継 続し、温度上昇を抑える効果がある。この点は耐火性能

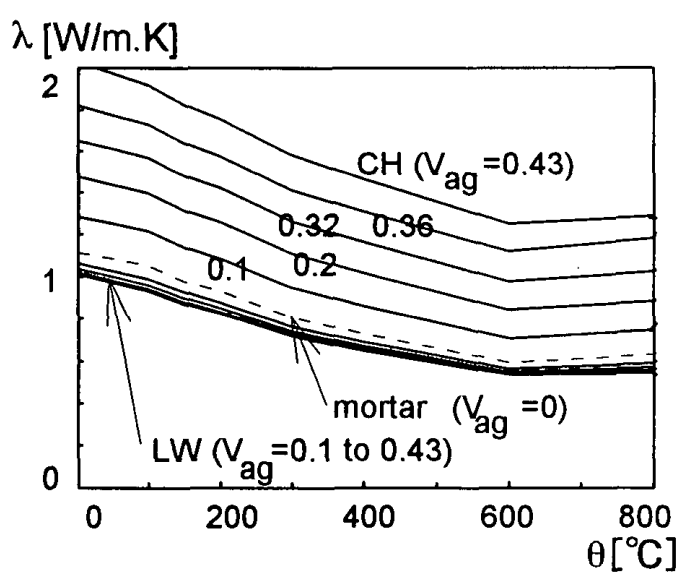

Fig.10 estimated thermal conductivity of chart $(\mathrm{CH})$ and lightweight (LW) concrete for various mix proportions.

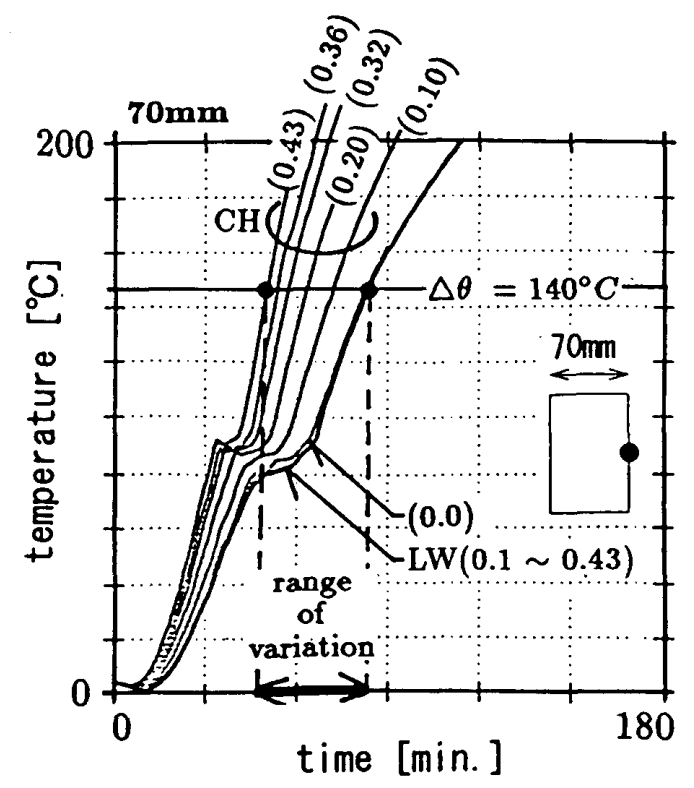

Fig. 11 calculated unexposed surface temperature of various mix proportions of coarse aggregate in case of chart $(\mathrm{CH})$ and lightweight $(\mathrm{LW})$ concrete.

に対して有利に働く。

そこで、前節の砂岩コンクリート(S1)について初期含 水率を $1 、 2 、 4 \%$ 変えて計算を行ない、非加熱側表 面温度経過の変化を調へた。含水率の増加に伴う熱伝導 率の変化は、空陌内ガスの一部が水で置換されたと考え ると Fig. 12 のように推算される。

非加熱側表面温度の経過を Fig. 13 に示す。初期含水 率が 1 \%の場合には温度の横ばいは約 4 分しか継続しな いが、4\%では約12分となる。そ机に伴い耐火時間が長 くなり、その変動範囲は64～74分となる。耐火時間の変 動が初期含水率に対して近似的に線形と見なすと、その 感度係数は $3.3[\mathrm{~min} . /(\%$-wt. )]となる。 


\section{$\lambda[\mathrm{W} / \mathrm{m} . \mathrm{K}]$}

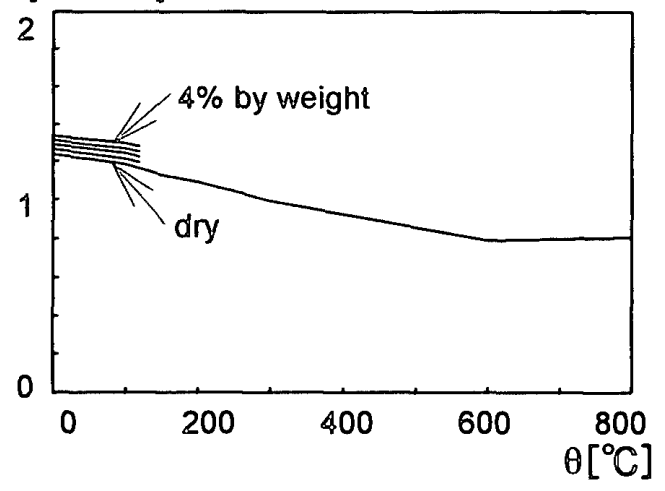

Fig. 12 variations in thermal conductivity by water content in case of sandstone (S1) concrete. (See Table 3 for mix proportions)

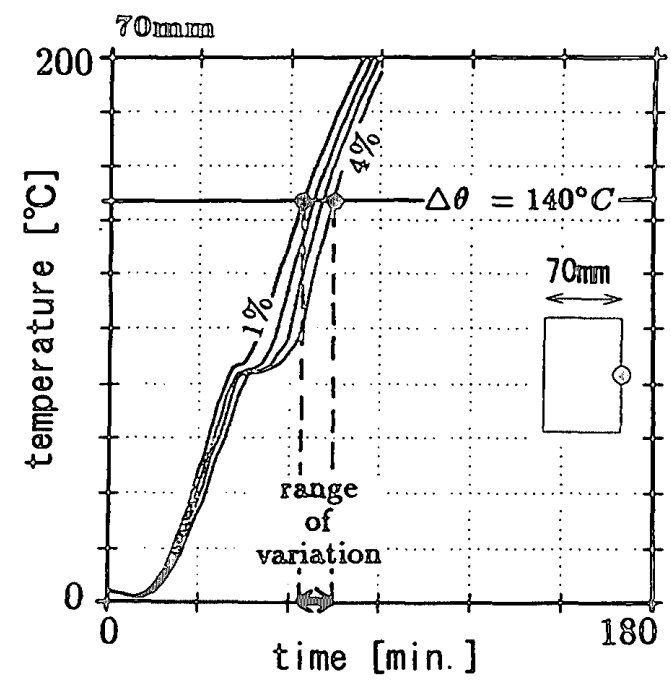

Fig.13 calculated unexposed surface temperature for different initial water content in case of sandstone concrete (See Table 3 for mix proportions.)

\section{4. 教察}

3. 1節の計算で得られた耐火時間を、阻骨材の熱伝 導率の常温から $8000^{\circ} \mathrm{C}$ まで平均值 $\overline{\lambda_{a g}}[\mathrm{H} / \mathrm{m} / \mathrm{K}]$

$\overline{\lambda_{\text {ag }}}=\frac{1}{780} \int_{20}^{800} \lambda_{\text {ag }}(\theta) d \theta$

と粗骨材の体積比率 $V_{a g}\left[\mathrm{~m}^{3} / \mathrm{m}^{3}\right]$ の関数として Fig. 14 に 示す。図中の黒丸が計算値であり、その他の点は内挿し てプロットしたものである。

この関係を利用して必要な耐火時間を得るための方法 について考察する。いま仮に70mmの壁に対して要求耐火 時間を60分とすると、Fig. 14 を利用して耐火時間が60分 以上となるようなコンクリートの調合を選へば良い。た だし、同図は初期含水率が $3 \%$ 場合について作成され
ているので、含水率の変動に対する余裕が必要である。 $\mathrm{F}$ ig. 13 より初期含水率が $3 \%$ 吅 $1 \%$ に変動すると耐火 時間は約 7 分短くなる。よって Fig. 14 にて耐火時間が6 7分となる簕囲の調合を選べば十分である。

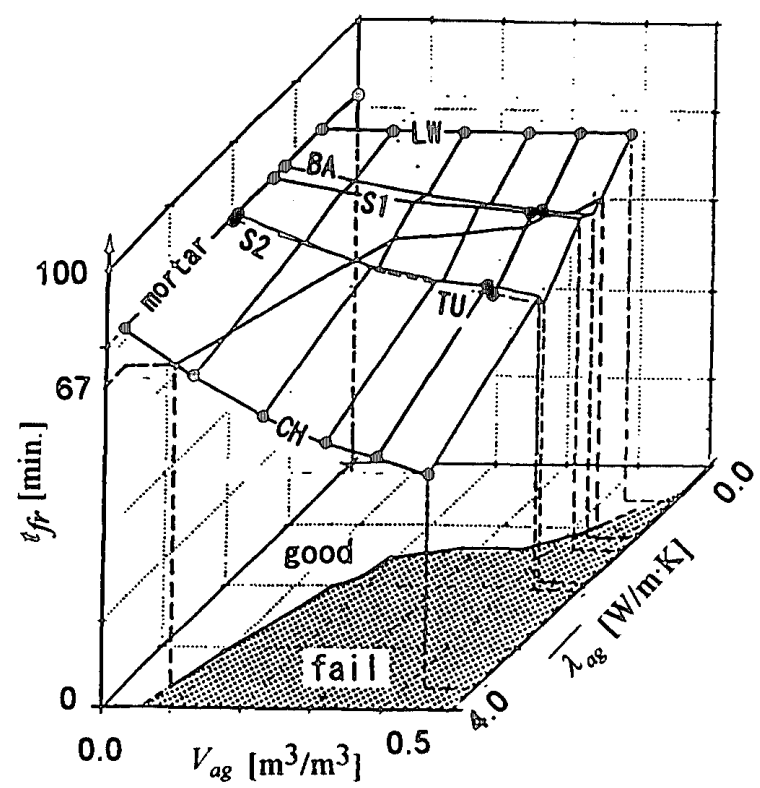

Fig.14 fire resistance time as a function of temperature averaged thermal conductivity of coarse aggregate defined by eq.(16) and volume fraction of coarse aggregate. Contour line $(67 \mathrm{~min}$.) shows the limit of mix proportions acceptable for 60 minutes of fire resistance, considering the variation of the initial water content.

\section{5. 跨論}

コンクリートの調合と初期含水率が而火性能に与え る影響を、熱水分移動のモテルを用いて定量化した。 コンクリートの調合については、粗骨材の種類（天然 骨材 5 種類、人工軽量骨材 1 種類）之体積比率の関数 として耐火時間を表した。その結果、耐火時間は骨材 の種類と量に大きく依存し、厚さ70mmの壁では、54〜8 3分の䉇囲で変動した。

初期含水率による変動についても検討し、初期含水 率が1〜4\%の範囲で変動すると、耐火時間は約10分変動 することを示した。

耐火性能に及ぽす度合を比較すると、コンクリート の調合によるものが圧倒的に大きい。このことから、 初期含水率の影響を近似的に線形に重祅あわせること により、要求耐火性能を満たすために許容されるコン クリートの調合の範囲を求める方法について考察した。 
注1）計算を行うと、各時刻での温度、空隙内ガスの全压 および水蒸気分压、物理吸着水および結晶水の含水率 の分布が得られる。本論文では、紙面の都合により、 非加熱側表面温度経過のみを示す。

\section{記号}

Alphabets

$A \quad$ pre-exponential factor $\left[\mathrm{s}^{-1}\right]$

$c$ heat capacity $[\mathrm{J} / \mathrm{kg} \cdot \mathrm{K}]$

$D_{v} \quad$ vapor diffusion coefficient $\left[\mathrm{m}^{2} / \mathrm{s}\right]$

$D_{w} \quad$ water diffusion coefficient $\left[\mathrm{m}^{2} / \mathrm{s}\right]$

$E \quad$ energy of activation $[\mathrm{J} / \mathrm{kmol} \cdot \mathrm{K}]$

$L_{s} \quad$ heat of sorption $[\mathrm{J} / \mathrm{kg}]$

$L_{d} \quad$ heat of decomposition $[\mathrm{J} / \mathrm{kg}]$

$M \quad$ molecular weight $[\mathrm{kg} / \mathrm{kmol}]$

$P \quad$ pressure $[\mathrm{Pa}]$

$R \quad$ universal gas constant $[=8314 \mathrm{~J} / \mathrm{kmol} \cdot \mathrm{K}]$

$R_{\text {sorp }} \quad$ rate of desorption $\left[\mathrm{kg} / \mathrm{m}^{3} \cdot \mathrm{s}\right]$

$R_{d c n i p}$ rate of decomposition $\left[\mathrm{kg} / \mathrm{m}^{3} \cdot \mathrm{s}\right]$

$T$ absolute temperature [K]

$t \quad$ time [s]

$t_{f}$. fire resistance time $[\mathrm{s}]$

$V \quad$ volume fraction $\left[\mathrm{m}^{3} / \mathrm{m}^{3}\right]$

$w \quad$ content of physically adsorbed water [kg/kg-dry]

$w_{c} \quad$ content of water of crystallization [ $\mathrm{kg} / \mathrm{kg}$-dry]

$w_{e q} \quad$ equilibrium water content $[\mathrm{kg} / \mathrm{kg}]$

Greek letters

$\begin{array}{ll}\varepsilon & \text { void fraction }\left[\mathrm{m}^{3} \text {-void } / \mathrm{m}^{3} \text {-bulk] }\right. \\ \gamma & \text { rate constant of desorption }\left[\mathrm{kg} / \mathrm{m}^{3} \cdot \mathrm{s}\right] \\ \lambda & \text { thermal conductivity }[\mathrm{W} / \mathrm{m} \cdot \mathrm{K}] \\ \rho & \text { density }\left[\mathrm{kg} / \mathrm{m}^{3} \text {-void] }\right. \\ \rho_{0} & \text { density of concrete }\left[\mathrm{kg} / \mathrm{m}^{3}\right] \\ \theta & \text { temperature }\left[{ }^{\circ} \mathrm{C}\right] \\ \theta_{f} & \text { fire temperature }\left[{ }^{\circ} \mathrm{C}\right] \\ \kappa_{D} & \text { Darcy's permeability }\left[\mathrm{m}^{2} / \mathrm{Pa} \cdot \mathrm{s}\right]\end{array}$

\section{subscripts}

a air

ag aggregate

g gaseous mixture

$\mathrm{k}$ stage of decomposition

p paste

s sand

$\mathrm{v} \quad$ vapor

$0 \quad$ reference (oven dry)

\section{参考文薪}

1) Harada, K., Terai, T., "Fire Resistance of Concrete Walls", Proc. 1st. Asian Conference on Fire Science and Technology, pp. $215-219,1992$

2) ISO834 - Fire Resistance Tests - Elements of Building Construction, 1985

3）昭和44年建設省告示第2999号、1969

4) Lee, T., T., Lin, T., D., "Fire Performance of Reinforced concrete Columns", Symp. on Applications of Fire Science to Fire Engineering, Denver, pp. 176-205,1984

5) 昭和39年建設省告示第1675号、1964

6) Harada, K., Terai, T., "Heat and Mass Transfer in an Intensely Heated Mortar Wall", Fire Safety Science, vol. 3, (Proc. 3rd Int. Symp. on Fire Safety Science), pp. 781 - 790, 1991

7) Terai, T., Harada, K., "Fire Behaviour of Concrete Members Taking into Account Simultaneous Transfer of Heat and Moisture", Proc. Asian Fire Seminar 93', pp. 49 - 58, Science University of Tokyo, 1993

8）寺井俊夫、原田和典、「火災時のコンクリートの熱伝 導とそのモテル」、第12回日本熱物性シンポジウム、 pp. 181-184, 1991

9) Maxwell, J., C., "A Treatise on Electricity and Magnetism", Vol. 1, Chapter IX, First Edition, General Publishing Company, Toronto, 1873

10) 原田和典、寺井悛夫、早崎伸一、「高温時のコンク リートの熱物性值に関する研究」、日本建築学会近畿 支部研究報告集、第29号・計画系、pp. 29-32、1989

11) 原田和典、寺井俊夫、「コンクリートの高温時の熱伝 導率推算方法に関する研究」、日本建築学会近畿支部 研究報告集、第32号・計画系、pp. 157-160、1992

12）「耐火試験時のコンクリート床内の熱及び水分同時移 動に関する研究」、昭和62年度文部省科学研究費補助 金 [試験研究(1)61850107、研究代表者:寺井俊夫] 研究 成果報告書、1988

13）上田哲夫、寺井俊夫、十倉毅、石原毅、小南和也、行 貝光史、「コンクリートの高温時の熱物性値に関する 実験的研究」、日本建築学会近畿支部研究報告集、第 27 号(計画系)、1987

14) 原田和典、寺井俊夫、「モルタル版の加熱実験の数值 計算によるシミュレーション」、日本建築学会大会 （中国）学術講演梗概集 A、pp. 1053 - 1054、1990

（1995年 4 月19日原稿受理，1995年11月 6 日採用決定） 